Volume 2

9-1-2011

\title{
From Mozart to Lookout: The Flute's Evolution from 1800
}

Anna J. Reisenweaver

Cedarville University, annajreisenweaver@cedarville.edu

Follow this and additional works at: https://digitalcommons.cedarville.edu/musicalofferings

Part of the Musicology Commons, Music Performance Commons, and the Music Practice Commons

DigitalCommons@Cedarville provides a publication platform for fully open access journals, which means that all articles are available on the Internet to all users immediately upon publication. However, the opinions and sentiments expressed by the authors of articles published in our journals do not necessarily indicate the endorsement or reflect the views of DigitalCommons@Cedarville, the Centennial Library, or Cedarville University and its employees. The authors are solely responsible for the content of their work. Please address questions to dc@cedarville.edu.

\section{Recommended Citation}

Reisenweaver, Anna J. (2011) "From Mozart to Lookout: The Flute's Evolution from 1800," Musical Offerings: Vol. 2 : No. 2 , Article 2.

DOI: 10.15385/jmo.2011.2.2.2

Available at: https://digitalcommons.cedarville.edu/musicalofferings/vol2/iss2/2 


\title{
From Mozart to Lookout: The Flute's Evolution from 1800
}

\section{Document Type}

Article

\begin{abstract}
As this brief survey of the flute's history and repertoire reveals, the instrument evolved significantly over the centuries. From works such as Mozart's Concerto in $\mathrm{G}$ to Robert Dick's Lookout, from the singlekeyed, four-piece flute of Jacob Denner to the highly complex mechanism of Alexander Murray, the flute's growth has been dramatic and extensive. While some of its technical changes were the result of new styles of repertoire, other innovations spurred musical developments as the instrument's capabilities expanded. As both the instrument and its repertoire grew simultaneously, the flute solidified its standing as in the classical tradition both a solo and orchestral instrument. The flute continues its evolution today as composers, players, and manufacturers continually experiment with new techniques and styles. Although the future is uncertain, history indicates that it will be as revolutionary as the past.
\end{abstract}

\section{Keywords}

Flute

Creative Commons License

\section{(c) (1) $9 \odot$}

This work is licensed under a Creative Commons Attribution-Noncommercial-No Derivative Works 3.0 License. 


\title{
From Mozart to Lookout: the Flute’s Evolution from 1800
}

\author{
Anna Reisenweaver \\ Cedarville University
}

\begin{abstract}
A s one of the oldest and most popular instruments in the Western musical 1 tradition, the flute has undergone many developments throughout its 1 history, evolving from a Prehistoric single-piece, keyless tube of bone or wood into the complex, mechanized instrument of today. Although several important innovations took place during the Medieval, Renaissance, and Baroque periods, the most significant and lasting developments to the instrument occurred during the Classical and Romantic eras, developments which ultimately gave the flute its modern form. These alterations to the instrument paralleled other changes in the repertoire as each area impacted the other, resulting in an overall rise in playing abilities and expectations. As a result of these innovations, the flute gained attention and popularity, solidifying its position as a vital part of Western classical music.
\end{abstract}

Several scholarly works have been written in this area, and Ardal Powell's The Flute, published in 2002, is among the most thorough and comprehensive. Powell's research traces the history of the flute since the medieval period, detailing the evolution of its construction, usage, and performance techniques. His work on the flute during the Classical through postmodern eras has been particularly useful in this study of the flute's history. Powell's discussion in this area begins with the development of the early keyed flute, relating this innovation to the increased demands being place on the instrument by a new style of solo performance and an increased presence in orchestral and other types of ensemble compositions. Powell continues his discussion with a survey of the Boehm flute, arguing that "the modern flute's invention can be traced to one man, since few more brilliant or controversial innovations in the design of any musical instrument can ever have been made than those Theobald Boehm devised for the flute." ${ }^{1}$ In his opinion, Boehm's developments brought the flute into its modern form. Powell continues by discussing further innovations to the instrument by subsequent makers, concluding his survey with an overview of the flute's evolution during the modern and postmodern eras.

Another notable resource in the area of flute history is Rachel Brown's The Early Flute: A Practical Guide, published in 2002. Like Powell's work, Brown's discussion contains a brief historical overview of the flute's development, technique, and style. Her research, however, covers a more limited scope and time frame, as she focuses primarily on the technical, mechanical, and stylistic

${ }^{1}$ Ardal Powell, The Flute (New Haven: Yale University Press, 2002), 164.

Musical Offerings, vol. 2, no. 2, pp. 33-47. ISSN 2167-3799

(C) 2011, Anna Reisenweaver, licensed under CC BY-NC-ND

(http://creativecommons.org/licenses/by-nc-nd/3.0/) 
evolutions of the sixteenth through eighteenth centuries. Her work has been most helpful in the area of Boehm's innovations, outlining clearly his history as a flutemaker and providing specific details on his inventions. She writes that Boehm, by placing the toneholes correctly and by developing a keywork to reach them, addressed and corrected the deficiencies of the simple-system flute. ${ }^{2}$ Brown also discusses the popularization of the Boehm flute, stating that "it was Boehm who possessed the genius, the craftsmanship and the business acumen to pursue, perfect, and promote his instruments in professional performances against considerable opposition.” 3

While the research by Brown and Powell is helpful in providing a broad overview of the flute's development, other works give an in-depth look at specific aspects of the instrument's history. Frederic von Huene's article "A Flûte Allemande in C and D by Jacob Denner of Nuremberg" provides insight into early Classical-era flute making by a thorough and detailed examination of an instrument crafted by Denner. Von Huene argues that this particular flute "can be considered the culmination of the early 18th-century three-piece flute design," ${ }^{4}$ with its interchangeable footjoints which gave the player greater flexibility of range and tuning. According to von Huene's examination and research of the instrument, the four-piece construction of Denner's flute allowed performers to adjust their tuning as needed, an innovation which lasted into the twentieth century until it was replaced by the Boehm flute. ${ }^{5}$ In addition to its flexible tuning system, the flute was also revolutionary, in von Huene's opinion, due to its extra footjoint that allowed the player to lower their range from $D^{1}$ to $C^{1}$, an innovation that was unique in Denner's time. Von Huene concludes his article by relating Denner's developments to the increasing prominence of the instrument during this time, writing that "his fine examples provide another reason why the flute d'allemande became this most favoured of all woodwinds." ${ }^{\prime \prime}$

Closely related to von Huene's research is that of Jean-Yves Rauline. In his article "19th-Century Amateur Music Societies in France and the Changes of Instrument Construction," Rauline explores the process by which new developments to instruments, such as those of Jacob Denner, were popularized among musicians of the day. Focusing specifically on nineteenth-century France, the author examines the reaction of amateur musical societies to the innovations of the day. In Rauline's opinion, "the different makers quickly understood the great benefits they could obtain from the development of amateur music societies,"7 using the

\footnotetext{
${ }^{2}$ Ibid., 26-27.

${ }^{3}$ Ibid., 27.

${ }^{4}$ Friedrich von Huene, “A Flûte Allemande in C and D by Jacob Denner of Nuremberg.” Early Music 23 No. 1 (Feb. 1995): 111. http://www.jstor.org/stable/3137806 (accessed February 4, 2011).

${ }^{5}$ Ibid., 107.

${ }^{6}$ Ibid., 111.

${ }^{7}$ Jean-Yves Rauline, "19th-Century Amateur Music Societies in France and the Changes of Instrument Construction.” The Galpin Society Journal 57 (May 2004): 236. http://www.jstor.org.library.cedarville.edu /stable/25163804 (accessed February 4, 2011).
} 
new improvements in instruments as opportunities for members to purchase these instruments. In addition to a push from instrument makers, amateur societies were encouraged to adopt new developments by the Orpheonic authorities, who at the time were seeking to adopt a standard pitch system and felt this process would be helped by the improved tuning systems of the new instruments. Rauline argues, however, that "despite the recommendations of the makers and the Orpheonic authorities, amateur musical societies adopted a middle way between passivity and progress throughout the nineteenth century. Far from submitting to the attractions of fashion, they preferred to keep their traditions without giving up the benefits of progress in instrument making whenever it was possible.”

A final area of specific research regarding the flute is Karyn Ann Berger's dissertation "Flute Intonation: A Comparison of Modern and Theobald Boehm Flutes Scales.” In her work, Berger provides an overview of both the Boehm and the modern, or Albert Cooper, flute scales and intonation systems, as well as specific experimentation with instruments of both types. Berger's work has been helpful in describing the significance of Boehm's improvements and in clarifying the differences between his flute and the modern instrument. She writes that "it was Boehm's ambition to improve flute intonation and tone quality and to extend the range of the flute" ${ }^{9}$ and relates several innovations which accomplished these goals. Berger then compares his work to that of Albert Cooper, a twentiethcentury flute-maker whose scale has become commonly used by many contemporary flute-makers.

This study of the flute's history seeks to combine this research with other scholarship in order to examine the influence that the instrument's technical developments have had upon the flute repertory. The innovations of Theobald Boehm and of those before and after him have permanently impacted the history of the flute, and a survey of this evolution will reveal the specific path taken to reach the modern instrument and its repertoire.

During the Classical era, several major developments to the instrument arose which set the stage for the Romantic-era work of Theobald Boehm and others. Towards the end of the Baroque period, the one-keyed, three-piece flute began to be manufactured in four parts in a new construction known as the corps de réchange. In this innovation, the upper middle joint of the flute was built with three to six interchangeable parts of different lengths, allowing the player to adapt to the wide variety of tuning systems present at the time. Although it is uncertain as to which flute-maker developed this construction, evidence points to Jacob Denner of Nuremberg, Germany, as one of the few makers whose work

\footnotetext{
${ }^{8}$ Ibid., 240.

${ }^{9}$ Karyn Ann Berger, "Flute Intonation: A Comparison of Modern and Theolbald Boehm Flutes Scales” (DMA Thesis, University of Cincinnati, 1999): 8.
} 
"documents the important transition from the three-jointed to the four-jointed flute.”10

Although the four-piece flute did compensate for some of the instrument's tuning difficulties, the instrument continued to have poor intonation and tone quality arising from the many cross-fingerings needed to play chromatically. This necessitated the development of chromatic keywork for the instrument, and around 1760, flute-makers Pietro Flori, Caleb Gedney, and Richard Potter, all of London, added three additional keys to the one-keyed flute. ${ }^{11}$ These keys allowed

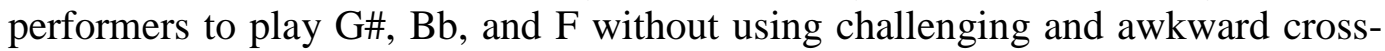
fingerings and clarified the tone of these previously "veiled" notes. In addition to these innovations, other makers lengthened the end of the flute and added two additional keys to extend the flute's range from $D^{4}$ downward to $C^{4}$. ${ }^{12}$ As manufacturers popularized these developments, yet another key was developed for the $\mathrm{F}$, known as a "long $\mathrm{F}$ " key, and an eighth key for $\mathrm{C}^{5}$ was also added, creating what is now known as the "simple-system" flute.

Although the addition of these keys solved some of the main problems of the flute, other difficulties arose in the development of the instrument. The new keys often leaked, causing intonation problems, the mechanism was somewhat unreliable, and players were reluctant to adopt the new fingering system necessitated by the additional keys. Further, the instrument was far from standardized, ${ }^{13}$ and "professional players of repute were using anything from one to eight keys." 14 A multiplicity of further innovations arose to improve upon the simple-system, including the Bb lever of Johann George Tromlitz, a development still used in modern flutes, and the larger tonehole sizes of Charles Nicholson. One of the most significant innovations to the Classical flute came in Rev. Frederick Nolan's flute of 1808, which was “designed to effect greater evenness of intonation." 15 Nolan's design called for "the construction of open-standing keys...the touch-pieces of which were in the form of rings surrounding one or other of the simple finger-holes." ${ }^{16}$ His work is commonly hailed as the first design to allow both an open key and a regular hole to be closed with the same finger, a design that remains fundamental to modern flute and was important to the later work of Theobald Boehm.

\footnotetext{
${ }^{10}$ Martin Kirnbauer and Peter Thalheimer, trans. Catherine Taylor, "Jacob Denner and the Development of the Flute in Germany,” Early Music 23, No. 1 (Feb. 1995): 96. http://0www.jstor.org.library.cedarville.edu/stable/3137805 (accessed February 4, 2011).

${ }^{11}$ Nancy Toff, The Development of the Modern Flute (Urbana: University of Illinois Press, 1986), 25.

${ }^{12}$ The numbering system of pitches is based on the lowest $C$ of the modern piano as $C^{1}$.

${ }^{13}$ Nancy Toff, The Development of the Modern Flute (Urbana: University of Illinois Press, 1986), 29.

${ }^{14}$ Philip Bate, The Flute (New York: Norton, 1979), 99.

${ }^{15}$ Nancy Toff, The Development of the Modern Flute (Urbana: University of Illinois Press, 1986), 35.

${ }^{16}$ Philip Bate, The Flute (New York: Norton, 1979), 107.
} 
The technological developments of the Classical flute had a direct relationship with the repertoire and performance of the time. The musical developments of the Baroque period, which "required increased instrumental flexibility in order to express the great depth of human feelings," 17 had inspired composers to increase the difficulty and complexity of their works. This prompted various innovations to the instrument, beginning in the Baroque era and coming to fruition in the Classical and Romantic eras as flutists sought to rise to the new standards of performance. In addition to these musical demands, the flute during the Classical period "was becoming the principal wind instrument for virtuosi,"18 with popular touring and orchestral performers such as Andrew Ashe, Louis Drouët, and Anton Fürstenau.

As the flute grew in popularity, composers and flutists such as Fürstenau, Jules Demersseman, and Jean-Louis Tulou wrote a large number of challenging virtuosic concerti and solo works. Other noted composers of the Classical era were commissioned to write for the instrument, such as Wolfgang Amadeus Mozart, whose compositions for flute remain standards for modern performers. As the works of this time increased in difficulty, the new developments to the instrument became essential in allowing players to perform these pieces. Mozart, for example, "often pushed the flute to extremes, utilizing its third octave extensively...assigning it chromatic passages and requiring it to play in different keys," 19 as in his Concerto in G Major, K. 313, which would have been played on the new simple-system flute: ${ }^{20}$

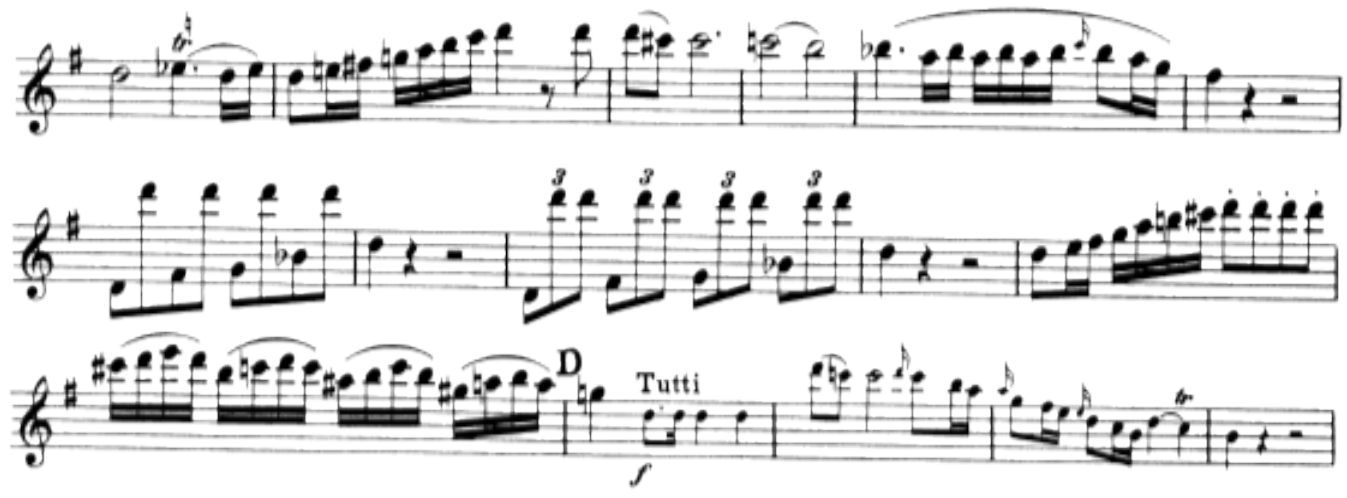

Ex. 1: Wolfgang Amadeus Mozart, Concerto in G Major, K. 313, mvt. 1

\footnotetext{
${ }^{17}$ Nancy Toff, The Development of the Modern Flute (Urbana: University of Illinois Press, 1986), 15.

${ }^{18}$ Ardal Powell, The Flute (New Haven: Yale University Press, 2002), 107.

${ }^{19}$ Bowers, Jane. “Mozart and the Flute.” Early Music 20 No. 1 (Feb. 1992): 34. http://0www.jstor.org.library. cedarville.edu/stable/3127667?seq=2 (accessed February 4, 2011).

${ }^{20}$ Wolfgang Amadeus Mozart. Flute Concerto No. 1 in G Major, K. 313. http://imslp.info/files/imglnks/usimg/d/db/ IMSLP31084-PMLP39820-

Mozart_Flute_Concerto_K313_Fl.pdf (accessed April 22, 2011).
} 
In addition to a growth in solo repertoire, composers began including the flute more frequently in orchestral and chamber ensembles, further increasing the difficulty and amount of music for the instrument. Franz Joseph Haydn's earlier symphonies, for example, typically confine the flute to the middle register, while his later works such as the Symphony No. 100 in G Major, "Military," expand its range up to $G^{6}{ }^{21}$ Ludwig van Beethoven also challenged the limits of the instrument's range in his works, demanding "a highly flexible instrument with the ability to produce any dynamic, any attack or legato from every note throughout the compass." 22 With the improved intonation and range of the simple-system instrument, players were better able to meet the demands of works such as Beethoven's Symphony No. 9, Op. 125: ${ }^{23}$

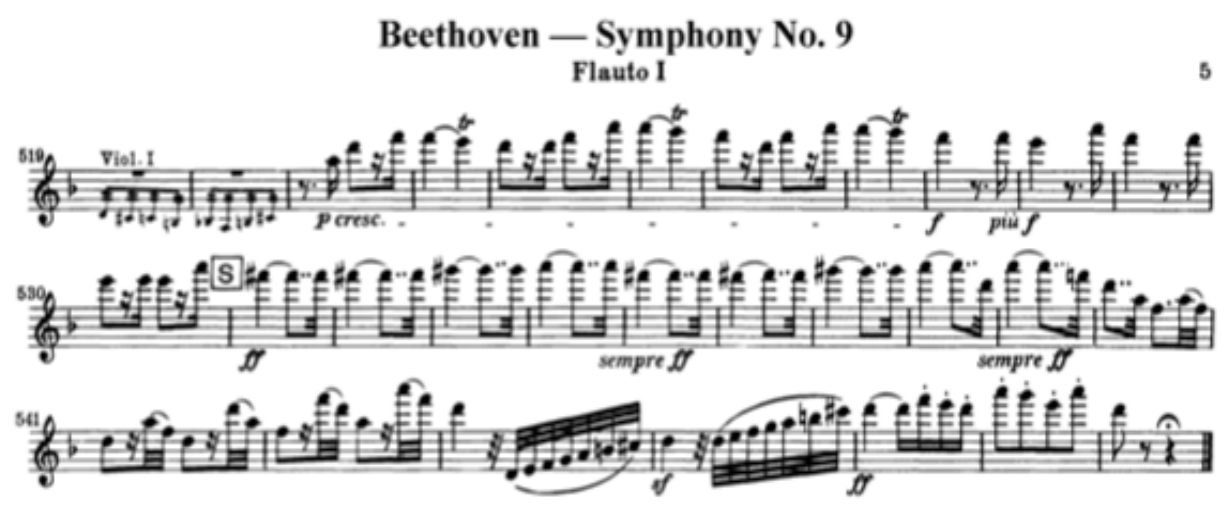

Ex. 2: Ludwig van Beethoven, Symphony No. 9, Op. 125, mvt. 1

Although the innovations of the Classical era produced significant improvements to the simple-system flute, a large number of defects continued to plague performers. As the flute solidified its position in the orchestral tradition and as its solo repertoire became increasingly challenging and virtuosic, its technical deficiencies, faulty intonation, and poor tone quality and projection were obvious. "The wooden German flute clearly could not fulfill the requirements of the nineteenth century," ${ }^{24}$ so much so that a complete redesign of the instrument became necessary during the Romantic period. This monumental project was undertaken by flutist and flute-maker Theobald Boehm of Munich, Germany, whose developments during the 1830s and 40s ultimately established the instrument's modern form. Ardal Powell writes of Boehm's work that "the modern flute's invention can be traced to one man, since few more brilliant or

\footnotetext{
${ }^{21}$ Nancy Toff, The Development of the Modern Flute (Urbana: University of Illinois Press, 1986), 27.

${ }^{22}$ Rachel Brown, The Early Flute: A Practical Guide (Cambridge: Cambridge University Press, 2002), 24.

${ }^{23}$ Ludwig van Beethoven. Symphony No. 9, Op. 125, http://216.129.110.22/files/imglnks/usimg/3/37/ IMSLP36799-PMLP01607-BeethovenOp125.Flute.pdf (accessed April 22, 2011).

${ }^{24}$ Rachel Brown, The Early Flute: A Practical Guide (Cambridge: Cambridge University Press, 2002), 45.
} 
controversial innovations in the design of any musical instrument can ever have been made than those Theobald Boehm devised for the flute in 1832 and 1847.”25 Boehm's radical changes to the instrument occurred in two stages. Although he had made some adaptations to the instrument in 1831 following a visit to London, during which he heard Charles Nicholson's powerful tone which was the result of enlarged toneholes, his first major adaptations to the instrument occurred in his 1832 flute. Based on the simple-system, conical-bore flute, Boehm's 1832 model made the toneholes as large as possible, placing them at their acoustically correct positions rather than at technically convenient locations as previous makers had done. In order to enable players to close these holes, Boehm used the earlier ringkey system of Nolan and his own new rod-axle mechanical system, resulting in an open-key format in which, "for the first time, all the flute's keys with the exception of the D\# key and special trill keys stood open in their default positions." 26 This allowed for the full venting of the holes, creating a larger, more resonant sound and leading Boehm to write that "as compared with the old flute, this one was unquestionably much nearer perfection.",27

Although Boehm's design significantly improved the intonation and tone quality of the instrument, it was not readily accepted by performers. It did, however, receive some approval in Paris after its introduction there in 1837 by Paul Hippolyte Camus, Louis Dorus, and Victor Jean Baptiste Coche. ${ }^{28}$ In response to this positive reception, flute-makers Louis Lot and Clair Godefroy made French versions of Boehm's system. Other French makers made minor modifications, including a closed G\# key developed by Dorus and a sleeve and clutch mechanism allowing a single rod to operate multiple keys created by Auguste Buffet. The flute was also manufactured in England by Rudall and Rose, but it was not well received in either that nation or Germany.

The second main stage of Boehm's developments occurred in his 1847 flute, a complete redesign of the instrument that, with some slight modifications, remains the basis for the modern flute. Although his 1832 flute had made definite improvements, "it seems...he still felt some doubts about its basic rationale," 29 choosing to significantly modify his earlier design in the later instrument. Boehm created his 1847 flute after a series of experiments in which he sought to determine the proper tonehole placement and bore shape and size in accordance with the mathematical laws of acoustics. The results of his experiments were recorded in his Schema, ${ }^{30}$ a diagram that outlined the dimensions of the flute and

\footnotetext{
${ }^{25}$ Ardal Powell, The Flute (New Haven: Yale University Press, 2002), 164.

${ }^{26}$ Ibid., 170.

27 Theobald Boehm, trans. Dayton C. Miller, The Flute and Flute-Playing in Acoustical, Technical, and Artistic Aspects (New York: Dover Publications, 1964), 8.

${ }^{28}$ Ardal Powell, The Flute (New Haven: Yale University Press, 2002), 170.

${ }^{29}$ Philip Bate, The Flute (New York: Norton, 1979), 125.

30 Theobald Boehm, Schema, "Boehm-Schema-full.gif 750x151 pixels," http://www.mcgeeflutes.com/images/ Boehm-Schema-full.gif (accessed April 23, 2011).
} 
allowed manufacturers to use the proper proportions "for a flute of whatever length was necessary to conform to the prevailing pitch standard:"31

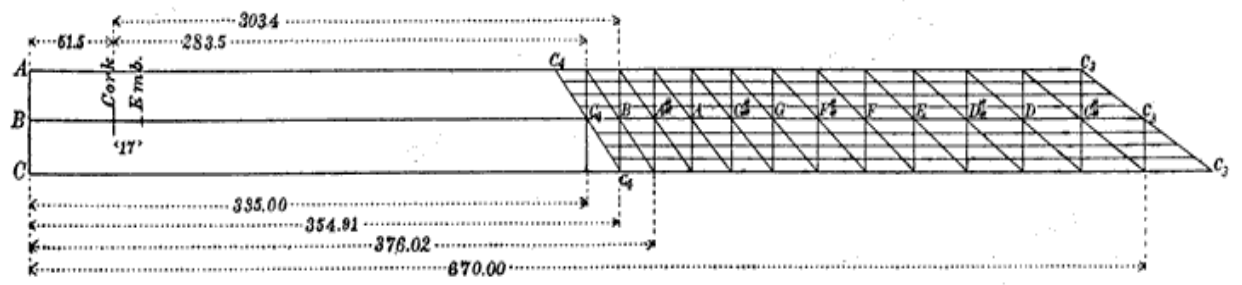

Ex. 3: Theobald Boehm, Schema

The instrument based on this schema, the 1847 flute, was noted for its cylindrical design in opposition to the older, conical model, of which Boehm writes: "I was never able to understand why, of all wind instruments with tone-holes and conical bore, the flute alone should be blown at its wider end." ${ }^{\text {32 }}$ Boehm established 19 millimeters as the optimal bore size for this flute, tapering to 17 millimeters at the top end of the headjoint, and his toneholes were placed at their proper acoustical and mathematical positions. The toneholes, too large to be covered by the fingers, were sealed with padded cups $^{33}$ which were attached to a mechanism adapted from Buffet's earlier rod and sleeve design. Finally, Boehm chose to construct this new flute from silver, stating that "the silver flute is preferable for playing....because of its great ability for tone modulation, and for the unsurpassed brilliancy and sonorousness of its tone," 34 although he also constructed versions in cocus or grenadilla wood. As a result of these alterations, flutists improved their intonation, enhanced their technique, and played with a bigger, more powerful tone quality.

Although the new flute was quickly popularized in France, England, and America, where it became the principal style manufactured by flute-makers, ${ }^{35}$ German flutists strongly resisted Boehm's system. Players and conductors in Boehm's native country objected to the sharp pitch tendencies of the upper octave, the new, more powerful tone, and, in particular, the new system of fingering. In response to the new instrument, German manufacturers such as Maximilian Schwedler and Friedrich Wilhelm Kruspe created a variety of developments to improve the older simple-system conical flute. Their instrument, known as the "Schwedler-Kruspe" or "Reform" flute, was essentially an elaborate simple-system flute, with an axle mechanism for the footjoint, a trill key for $\mathrm{D}^{6}-\mathrm{E}^{6}$, and "the usual long and cross

\footnotetext{
${ }^{31}$ Nancy Toff, The Development of the Modern Flute (Urbana: University of Illinois Press, 1986), 69.

32 Theobald Boehm, trans. Dayton C. Miller, The Flute and Flute-Playing in Acoustical, Technical, and Artistic Aspects (New York: Dover Publications, 1964), 10.

${ }^{33}$ Ardal Powell, The Flute (New Haven: Yale University Press, 2002), 182.

34 Theobald Boehm, trans. Dayton C. Miller, The Flute and Flute-Playing in Acoustical, Technical, and Artistic Aspects (New York: Dover Publications, 1964), 54.

${ }^{35}$ Ardal Powell, The Flute (New Haven: Yale University Press, 2002), 194.
} 
F's and the side C key." 36 Although the "Reform" flute was popular in Germany for a time, "the Boehm flute and other cylindrical models became more common as flute-making reached a new stage of industrialization in the mid-nineteenth century" ${ }^{37}$ and as players increasingly recognized the superiority of the Boehm system flute.

As the various developments of Boehm, Schwedler, and Kruspe began to take hold, "the skill of flute players also scaled new heights." 38 Studies and technical exercises of the Romantic period indicate a high level of technical proficiency, and virtuosic showpieces, most of which lacked musical substance, were written by composers or even flute-makers such as Boehm to demonstrate the abilities of players of the new instruments. ${ }^{39}$

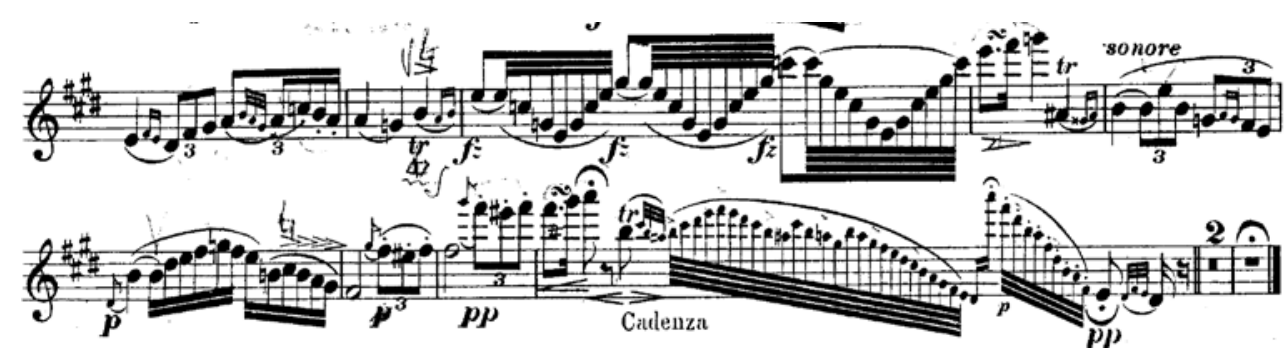

Ex. 4: Theobald Boehm, Variations sur un Air Allemand, Op. 22

Despite the insubstantial, showy solo repertoire and the reduced popularity of the touring flute virtuoso, the flute did solidify its position as an important member of the orchestral ensemble during the Romantic era. Works by composers such as Johannes Brahms, Pyotr Ilyich Tchaikovsky, and Richard Strauss stretched the limits of the instrument, and the flute's technical developments were vital in helping players achieve these new performance standards. Brahms, in his Symphony No. 4 in E minor, Op. 98, for example, extended the range upwards to $\mathrm{C}^{7}$, while Strauss in Ein Heldenleben pushed it to $\mathrm{D}^{7}$, limits previously untested in compositions. Tchaikovsky and Brahms also demanded a dark, controlled low register for the instrument, with Tchaikovsky writing parts down to low $\mathrm{B}^{3}$ in his Symphony No. 6 in B minor, Op. 74, "Pathétique." 40

\footnotetext{
${ }^{36}$ Nancy Toff, The Development of the Modern Flute (Urbana: University of Illinois Press, 1986), 83.

${ }^{37}$ Ardal Powell, The Flute (New Haven: Yale University Press, 2002), 199.

38 James Galway, Flute (New York: Schirmer, 1982), 46.

39 Theobald Boehm, Variations sur un Air Allemand, Op. 22, http://erato.uvt.nl/files/imglnks/usimg/d/d2/ IMSLP48639-

PMLP102920Boehm_Variations_sur_un_Air_allemnd_op22_Flute.pdf (accessed April 23, 2011).

${ }^{40}$ Pyotr Ilyich Tchaikovsky, Symphony No. 6 in B minor, Op. 74, "Pathétique,” http://216.129.110.22/files/imglnks /usimg/0/02/IMSLP38808-PMLP02511-TchaikovskyOp74.Flute.pdf (accessed April 23, 2011).
} 


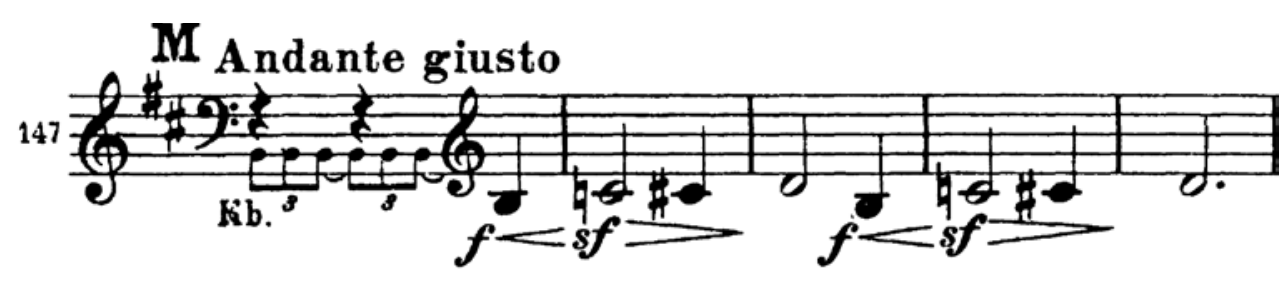

Ex.5: Pyotr Ilyich Tchaikovsky, Symphony No.6 in B minor "Pathétique,” Op. 74, mvt. 4, mm. 147-151.

Since the development of the Boehm system, the flute's construction has remained fairly stable throughout the Modern era. After Boehm's time, "experiments with new fingering systems have been relatively infrequent, and even these few have been confined to partial modifications of the Boehm system." ${ }^{41}$ Flute-makers of the early twentieth century revised Boehm's ideas to correct certain problems or difficulties with the instrument, such as the tendency of certain notes in the first octaves to be flat and others in the third octave to be sharp. Makers Djalma Juillot and François Borne, for example, added a split E key, a thumb and second lever for the G\# key, and a C\# trill key, among other innovations. In Britain, flute-maker John William McAvoy, in his attempts to simplify Boehm's chromatic fingering, ironically created a much more complicated instrument. Later in the century, flutist Alexander Murray also sought to redesign the Boehm flute. Murray chose to preserve the original open G\# key of Boehm's design and, concerned with the "asymmetrical use of the little fingers and the necessity of depressing the right-hand little finger most of the time," 42 also designed an open D\# key. This led to a wide range of other mechanical alterations, ultimately resulting in a highly complex instrument that is impractical to manufacture commercially ${ }^{43}$ and that is played primarily only by Murray’s own students.

Although a large number of these modifications were rather unsuccessful and short-lived, the work of flute-maker Albert Cooper stands out as one of the most important developments to the modern flute. As Sir James Galway writes, "Albert Cooper...has brought the flute near to perfection" 44 with his Cooper Scale, which he developed in 1973. Seeking to correct the intonation difficulties of the Boehm flute, Cooper "began with a mathematical calculation to devise his new scale, and then altered the tone hole placement within that original calculation to account for individual intonation discrepancies of each note." 45 Cooper began his scale by

\footnotetext{
${ }^{41}$ Nancy Toff, The Development of the Modern Flute (Urbana: University of Illinois Press, 1986), 128.

${ }^{42}$ Ibid., 142.

${ }^{43}$ Ibid., 157.

${ }^{44}$ James Galway, Flute (New York: Schirmer, 1982), 48.

${ }^{45}$ Karyn Ann Berger, "Flute Intonation: A Comparison of Modern and Theobald Boehm Flutes Scales” (DMA Thesis, University of Cincinnati, 1999), 12.
} 
determining the exact distance between $\mathrm{C}^{4}$ and $\mathrm{C}^{5}$, then placed the $\mathrm{A}$ hole to provide an exact interval between the notes, concluding by dividing the octave equally between the remaining tone holes. This scale corrects the Boehm flute's internal intonation problems, and Cooper writes of his work that "I now feel that I have more or less reached the end of the road scalewise." ${ }^{46}$ His scale currently provides the basis for the systems of many flute-makers, who have continued to develop it to further improve the flute's intonation.

Although some of the technical innovations to the flute have survived, such as the Cooper Scale, many more, such as the Murray and McAvoy flutes, "have been abandoned as just so much hardware." 47 Throughout the Modern era, the instrument has enjoyed a relative amount of stability due, in large part, to the internationalization of flute-playing style and technique. Following World War II, "an international mainstream of teaching, performing style, manufacturing, and recording emerged" 48 based on the teachings and techniques of the French flute school at the Paris Conservatoire. As the playing of master teachers and performers such as Claude-Paul Taffanel, Jean-Pierre Rampal, and Marcel Moyse gained popularity and renown, flutists around the globe sought to emulate their style, and as a result the silver Boehm flute of that school became the standard instrument for performers everywhere. In addition to the influence of the French school, the advent of mass production and a growing music education system made a standardization of the instrument necessary, ${ }^{49}$ with only minor changes to the instrument having a permanent impact on its construction.

As the flute became standardized during the Modern era, the levels of performance rose dramatically. The new instruments provided an expanded range, a wider variety of timbres, and better mechanical technique. Composers such as Claude Debussy and Olivier Messiaen took advantage of the instrument's expanded abilities in works such as Prélude a l'après-midi d'un faune and Le merle noir, ${ }^{50}$ demanding a wide range of colors and styles and increasing the technical demands placed on flutists.

\footnotetext{
${ }^{46}$ Albert Cooper, "My Work on Flutes” in Flute, James Galway (New York: Schirmer, 1982), 50.

${ }^{47}$ Nancy Toff, The Development of the Modern Flute (Urbana: University of Illinois Press, 1986), 130.

${ }^{48}$ Ardal Powell, The Flute (New Haven: Yale University Press, 2002), 264.

${ }^{49}$ Nancy Toff, The Development of the Modern Flute (Urbana: University of Illinois Press, 1986), 129.

${ }^{50}$ Olivier Messiaen, Le Merle Noir (Paris: Alphonse Leduc et Cie., 1952).
} 

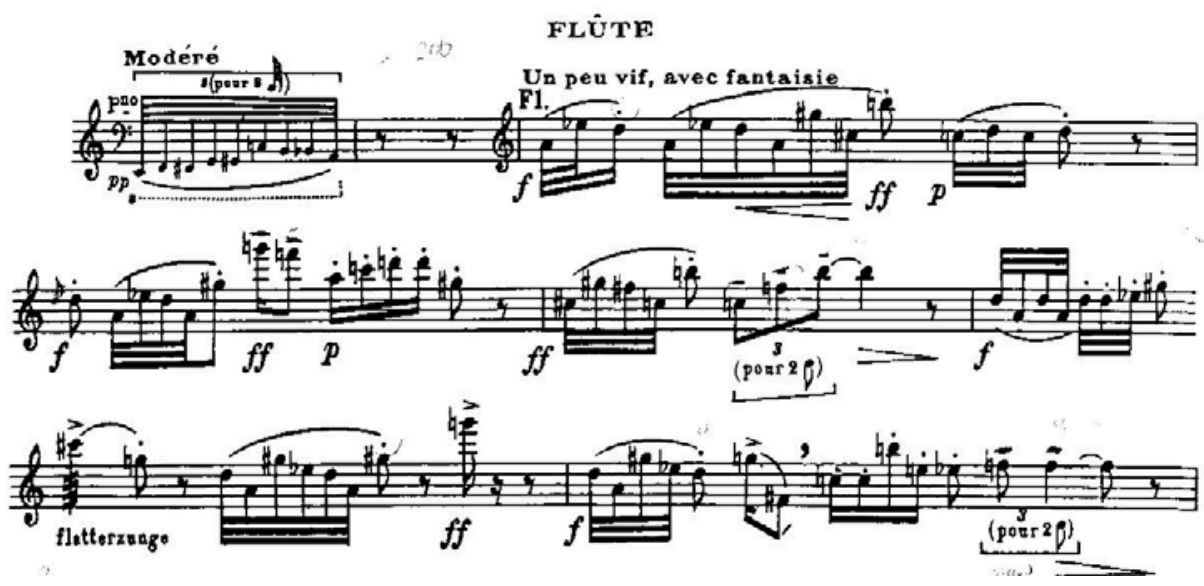

Ex. 6: Olivier Messiaen, Le merle noir

With the advent of avant-garde repertoire during the late twentieth century, new demands in sonority and technique are being placed on flutists. Known as extended techniques, sounds such as multiphonics, fluttertonguing, harmonics, and other auxiliary sounds are frequently used in modern music. These technical demands, arising from the improved abilities of the modern flute, have, in turn, spurred additional experiments, such as the quarter-tone flute of Eva Kingma and the Glissando headjoint of Robert Dick, both designed to facilitate some of these new sounds. A key innovator in the development of extended techniques, Dick features many of these sonorities in works such as Lookout. ${ }^{51}$ In this piece, Dick also uses an altered system of notation, including square noteheads to represent throat-tuning, multiple notes to indicate multiphonics, and " $x$ " shaped notes to notate key clicks. Typically, extended techniques such as these use different fingerings, such as multiphonics, while others, such as throat-tuning, require the player to sing in the throat and play the flute simultaneously. These techniques are usually explained in an introduction, and new fingerings may also appear within the music itself.
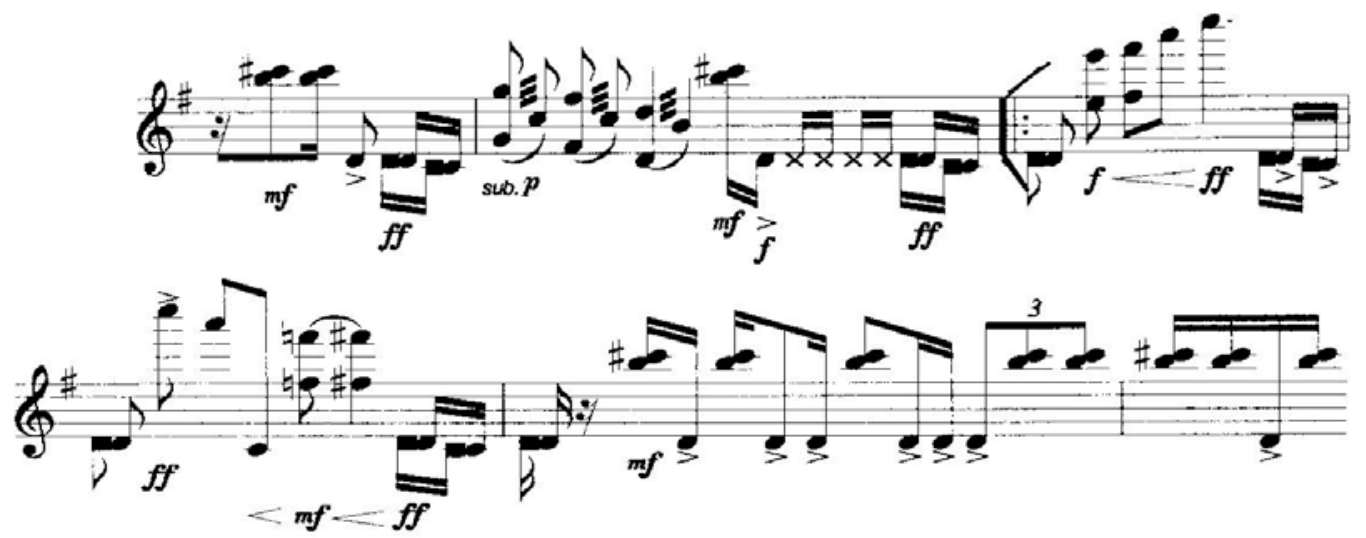

Ex. 7: Robert Dick, Lookout

${ }^{51}$ Robert Dick, Lookout (Multiple Breath Music Company, 1989). 
As this brief survey of the flute's history and repertoire reveals, the instrument evolved significantly over the centuries. From works such as Mozart's Concerto in G to Robert Dick's Lookout, from the single-keyed, four-piece flute of Jacob Denner to the highly complex mechanism of Alexander Murray, the flute's growth has been dramatic and extensive. While some of its technical changes were the result of new styles of repertoire, other innovations spurred musical developments as the instrument's capabilities expanded. As both the instrument and its repertoire grew simultaneously, the flute solidified its standing as in the classical tradition both a solo and orchestral instrument. The flute continues its evolution today as composers, players, and manufacturers continually experiment with new techniques and styles. Although the future is uncertain, history indicates that it will be as revolutionary as the past.

\section{Bibliography}

Badger, Alfred G. An Illustrated History of the Flute. New York: Firth, Pond \& Co., 1853.

Bate, Philip. The Flute. New York: Norton, 1979.

Beethoven, Ludwig van. Symphony No. 9, Op. 125. http://216.129.110.22/files/imglnks/ usimg/3/37/IMSLP36799-PMLP01607-Beethoven-Op125.Flute.pdf (accessed April 22, 2011).

Berger, Karyn Ann. "Flute Intonation: A Comparison of Modern and Theobald Boehm Flutes Scales.” DMA Thesis, University of Cincinnati, 1999.

Boehm, Theobald. Translated by Dayton C. Miller. The Flute and Flute-Playing in Acoustical, Technical, and Artistic Aspects. New York: Dover Publications, 1964.

Boehm, Theobald. Variations sur un Air Allemand, Op. 22. http://erato.uvt.nl/files/imglnks/usimg/d/d2/IMSLP48639-PMLP102920Boehm_Variations_sur_un_Air_allemnd_op22_Flute.pdf (accessed April 23, 2011).

Bowers, Jane. “Mozart and the Flute.” Early Music 20 No. 1 (Feb. 1992): 31-42. http://0-www.jstor.org.library.cedarville.edu/stable/3127667?seq=2 (accessed February 4, 2011).

Brown. Rachel. The Early Flute: A Practical Guide. Cambridge: Cambridge University Press, 2002. 
Cooper, Albert. “My Work on Flutes.” In Flute, James Galway. New York: Schirmer, 1982.

Dick, Robert. "Flutist Robert Dick Demonstrates the Glissando Headjoint.” ArtistshouseMusic.

http://www.artistshousemusic.org/videos/flutist+robert+dick+demonstrate s+the +glissando+headjoint. Video (accessed February 4, 2011).

Dick, Robert. Lookout. Multiple Breath Music Company, 1989.

Dolmetsch, Carl. "Recorder and German Flute during the 17th and 18th Centuries.” Proceedings of the Royal Musical Association 83rd Sess. (1956-57): 49-63. http://www.jstor.org/stable/766064. (accessed February 4, 2011).

Galway, James. Flute. New York: Schirmer, 1982.

von Huene, Friedrich. "A Flûte Allemande in C and D by Jacob Denner of Nuremberg.” Early Music 23 No. 1 (February 1995): 102-112. http://www.jstor.org/stable/3137806 (accessed February 4, 2011).

Kirnbauer, Martin and Peter Thalheimer. Translated by Catherine Taylor. "Jacob Denner and the Development of the Flute in Germany.” Early Music 23, No. 1 (Feb. 1995): 82-100. http://www.jstor.org/stable/3137805. (accessed February 4, 2011).

Messiaen, Olivier. Le Merle Noir. Paris: Alphonse Leduc et Cie., 1952.

Meylan, Raymond. The Flute. London: B.T. Batsford Ltd, 1988.

Mozart, Wolfgang Amadeus. Flute Concerto No. 1 in G Major, K. 313. http://imslp.info/files/ imglnks/usimg/d/db/IMSLP31084-PMLP39820Mozart_Flute_Concerto_K313_Fl.pdf (accessed April 22, 2011).

Powell, Ardal. The Flute. New Haven: Yale University Press, 2002.

. "Science, Technology and the Art of Flute Making in the Eighteenth Century." Flutehistory.com. http://www.flutehistory.com/Resources/Documents/technology.php3 (accessed December 14, 2010).

Rauline, Jean-Yves. "19th-Century Amateur Music Societies in France and the Changes of Instrument Construction.” The Galpin Society Journal 57 (May 2004): 236-45. http://0- 
www.jstor.org.library.cedarville.edu/stable/25163804 (accessed February 4, 2011).

Tchaikovsky, Pyotr Ilyich. Symphony No. 6, Op. 74, "Pathétique.” http://216.129.110.22/files/ imglnks/usimg/0/02/IMSLP38808-PMLP02511-TchaikovskyOp74.Flute.pdf (accessed April 23, 2011).

Toff, Nancy. The Development of the Modern Flute. Urbana: University of Illinois Press, 1986. 